\title{
VAV1 wt Allele
}

National Cancer Institute

\section{Source}

National Cancer Institute. VAV1 wt Allele. NCI Thesaurus. Code C52957.

Human VAV1 wild type allele is located in the vicinity of 19p13.2 and is approximately 85 $\mathrm{kb}$ in length. This allele, which encodes proto-oncogene vav protein, plays a role in both hematopoiesis and T-cell and B-cell regulation. 